\title{
GIP-Dependent Expression of Hypothalamic Genes
}

\author{
S. AMBATI ${ }^{1}$, J. DUAN ${ }^{1}$, D. L. HARTZELL ${ }^{1}$, Y.-H. CHOI ${ }^{3}$, M. A. DELLA-FERA ${ }^{1}$, \\ C. A. BAILE ${ }^{1,2}$
}

${ }^{1}$ Department of Animal and Dairy Science, University of Georgia, Athens, USA, ${ }^{2}$ Department of Foods and Nutrition, University of Georgia, Athens, USA, ${ }^{3}$ Department of Animal Science and Institute of Agriculture \& Life Sciences, Gyeongsang National University, Jinju, Korea

Received January 14, 2011

Accepted September 1, 2011

On-line October 12, 2011

\section{Summary}

GIP (glucose dependent insulinotrophic polypeptide), originally identified as an incretin peptide synthesized in the gut, has recently been identified, along with its receptors (GIPR), in the brain. Our objective was to investigate the role of GIP in hypothalamic gene expression of biomarkers linked to regulating energy balance and feeding behavior related neurocircuitry. Rats with lateral cerebroventricular cannulas were administered $10 \mu \mathrm{g}$ GIP or $10 \mu \mathrm{l}$ artificial cerebrospinal fluid (aCSF) daily for 4 days, after which whole hypothalami were collected. Real time Taqman $^{\mathrm{TM}}$ RT-PCR was used to quantitatively compare the mRNA expression levels of a set of genes in the hypothalamus. Administration of GIP resulted in up-regulation of hypothalamic mRNA levels of AVP (46.9 $\pm 4.5 \%)$, CART $(25.9 \pm 2.7 \%)$, CREB1 $(38.5 \pm 4.5 \%)$, GABRD $(67.1 \pm 11 \%)$, JAK2 $(22.1 \pm 3.6 \%)$, MAPK1 $(33.8 \pm 7.8 \%)$, NPY $(25.3 \pm 5.3 \%)$, OXT $(49.1 \pm 5.1 \%)$, STAT3 $(21.6 \pm 3.8 \%)$, and $\mathrm{TH}(33.9 \pm 8.5 \%)$. In a second experiment the same set of genes was evaluated in $\mathrm{GIPR}^{-1-}$ and $\mathrm{GIPR}^{+/ ?}$ mice to determine the effect of lack of GIP stimulation on gene expression. In $\mathrm{GIPR}^{-/}$mice expressions of the following genes were down-regulated: AVP $(27.1 \pm 7.5 \%)$, CART $(28.3 \pm 3.7 \%)$, OXT $(25.2 \pm 5.8 \%)$, PTGES $(23.9 \pm 4.5 \%)$, and STAT3 $(8.8 \pm 2.3 \%)$. These results suggest that AVP, CART, OXT and STAT3 may be involved in energy balance-related hypothalamic circuits affected by GIP.

\section{Key words}

GIP receptor knockout • ICV administration • mRNA expression • Rats • Mice

\section{Corresponding author}

C. A. Baile, 444 Rhodes Center, University of Georgia, Athens GA 30602-2771, USA. Fax: (706) 542-7925. E-mail: cbaile@uga.edu

\section{Introduction}

Gastric inhibitory polypeptide (GIP) is a 42 amino acid peptide hormone, synthesized by $\mathrm{K}$ cells in the intestinal epithelium (Buchan et al. 1978) and released into the circulation in response to nutrient ingestion. It was renamed glucose dependent insulinotropic polypeptide, reflecting its important role as a hormone in gut physiology. GIP stimulates insulin secretion, and potentiates the action of insulin in adipose tissue and other target tissues (Moens et al. 1996, Yip and Wolfe 2000, Wideman and Kieffer 2004). GIP receptors were reported to be present in the pancreas, gut, adipose tissue, adrenal cortex and heart, and pituitary, as well as in several brain regions, including the cerebral cortex, hippocampus, hypothalamus and olfactory bulb (Usdin et al. 1993, Kaplan and Vigna 1994). Expression of GIP has also been reported in these brain regions (Nyberg et al. 2005, Sondhi et al. 2006).

The secretin family of peptides, of which GIP is a member, have been reported to be involved in a variety of brain functions such as neuro-modulation, neurogenesis, brain development, cell-cycle regulation, differentiation, and cell death as well as in regulation of food intake, body weight and body temperature (Sherwood et al. 2000, Nyberg et al. 2005). GIP also appears to have a role in bone metabolism, with GIP receptor knockout $\left(\mathrm{GIPR}^{-/}\right)$mice exhibiting reduced bone mass, whereas transgenic mice with GIP overexpression have increased bone mass (Ding et al. 2008).

GIP regulates lipid metabolism and storage (Holst 2004) partly through its effect on insulin secretion 
and the resulting increased uptake and incorporation of glucose into lipids, as well as through direct effects in adipose tissue (Wasada 1981, Hauner et al. 1988, Yip and Wolfe 2000, Wideman and Kieffer 2004). GIPR ${ }^{-/-}$mice were found to be resistant to diet-induced obesity and insulin resistance, and GIP has been considered as a potential pharmaceutical target in the treatment of diabetes, obesity and other metabolic disorders (Miyawaki et al. 2002, Kieffer 2003).

The objective of this study was to determine whether central administration of GIP altered expression of genes known to be involved in regulation of food intake and body energy balance and whether GIP receptor deficiency would result in opposite changes in expression of some or all of those genes. We report that GIP administered centrally to rats reduced body weight gain and induced changes in several genes involved in energy balance regulation. Furthermore, we identified a subset of those genes showing the opposite changes in expression in $\mathrm{GIPR}^{-/-}$mice compared to $\mathrm{GIPR}^{+/ ?}$ mice.

\section{Material and Methods}

Male Sprague-Dawley rats (250-274 g) purchased from Harlan, Inc. (Indianapolis, IN) were used in the experiments 1 and 2. Ten week old C57BL6 $\mathrm{GIPR}^{+/ ?}(\mathrm{n}=20)$ and $\mathrm{GIPR}^{-/-}$mice $(\mathrm{n}=18)$ were obtained from Dr. Carlos Isales (Medical College of Georgia). Two pairs of homozygous mice $\left(\mathrm{GIPR}^{-/}\right)$with targeted disruptions of exon 4 and 5 of the GIPR gene were originally obtained from the laboratory of Dr. Yuichiro Yamada (Department of Metabolism and Clinical Nutrition, Kyoto University Graduate School of Medicine, Kyoto, Japan), from which a breeding colony was established. The GIPR knockout mice were generated, bred, and maintained in the C57BL/6 line (Miyawaki et al. 1999). These mice were bred and maintained on a $\mathrm{C} 57 \mathrm{Bl} / 6$ genetic background in Dr. Isales' facility. Mice were kept four animals/cage, at $25{ }^{\circ} \mathrm{C}$ with a $12 / 12 \mathrm{~h}$ light/dark cycle. They had free access to a standard diet (Harlan TakLad Rodent Diet (W) 8604) and water ad libitum. Rats were housed singly in a light (12 h on/12h off) - and temperature controlled environment $\left(22 \pm 1{ }^{\circ} \mathrm{C}\right.$, humidity $\left.50 \%\right)$. Rats were fed standard rodent chow and provided with water ad libitum.

Effect of icv injection of GIP on food intake and weight gain in rats

Rats were implanted with chronic lateral cerebroventricular cannulas as previously described (Choi et al. 2003), and after recovery from surgery, they were randomly assigned to four groups $(n=8)$. Control rats were administered $10 \mu \mathrm{l}$ artificial cerebrospinal fluid $(a \mathrm{CSF})$ at 24-hour intervals for 4 days. The GIP treated rats were administered $0.1,1.0$ or $10 \mu \mathrm{g}$ /day GIP in $10 \mu \mathrm{l}$ $a \mathrm{CSF}$ for 4 days. The injections were carried out using an injector cannula (C313I, Plastics One, Roanoke, VA) that protruded $1.1 \mathrm{~mm}$ below the tip of the guide cannula and that was connected to a Gilmont microsyringe by way of polyethylene tubing (PE20 Intramedic, Cat. \#427406, BD, Sparks, MD). Food and water were available ad libitum. Food intake was measured daily and rats were weighed daily. All experiments and surgical procedures were performed in accordance with the guidelines approved by the Institutional Animal Care and Use Committee of the University of Georgia. Twenty-four hours after the last icv injection, rats were killed by decapitation after a brief exposure to carbon dioxide.

\section{Effect of icv injection of GIP on gene expression in rats}

Rats were implanted with chronic lateral cerebroventricular cannulas as previously described (Choi et al. 2003), and after recovery from surgery, they were randomly divided into two groups $(n=8)$. Control rats were administered $10 \mu \mathrm{l}$ artificial cerebrospinal fluid ( $a \mathrm{CSF})$ at 24-hour intervals for 4 days; the GIP-treated rats were administered $10 \mu \mathrm{g}$ /day GIP in $10 \mu \mathrm{l} a \mathrm{CSF}$ for 4 days. The dose used was selected based on the results of the previous experiment. Food and water were available ad libitum. Twenty-four hours after the last injection rats were killed by decapitation after a brief exposure to carbon dioxide. The brains were removed rapidly after decapitation and immediately frozen by placing them on plastic cassettes on top of powdered dry ice. Once completely frozen, they were stored at $-80^{\circ} \mathrm{C}$. The brains were thawed to $-20{ }^{\circ} \mathrm{C}$ before the hypothalamic dissection.

\section{Hypothalamic gene expression in $G_{P} R^{-/-}$mice}

In this experiment the hypothalamic gene expression profile of $\mathrm{GIPR}^{+/ ?}$ mice was compared to that from $\mathrm{GIPR}^{-/}$mice. Mice were deeply anesthetized with $\mathrm{CO}_{2}$ before decapitation. The brains were removed rapidly after decapitation and immediately frozen on powdered dry ice. They were stored at $-80^{\circ} \mathrm{C}$. The brains were thawed to $-20{ }^{\circ} \mathrm{C}$ before the hypothalamic dissection. Hypothalamic blocks from two mice of the same group were randomly pooled together for RNA extraction. 
Extraction of total $R N A$, reverse transcription (RT) and real-time $P C R$

Total hypothalamic RNA was extracted using Trizol Reagent (Invitrogen, Carlsbad, CA) in accordance with the manufacturer's protocol. The integrity of the total RNA obtained from all the samples were verified using the RNA 6000 Nano Assay and the Agilent 2100 Bioanalyzer (Agilent Technologies, Palo Alto, CA). The $\mathrm{RT}$ reaction was performed on $100 \mathrm{ng}$ of total RNA per sample in a $20 \mu$ l reaction mixture using the $c$ DNA Archive Kit with MultiScribe ${ }^{\mathrm{TM}}$ Reverse Transcriptase (Applied Biosystems, Inc., ABI, Foster City, CA) according to the manufacturer's instructions. Reactions were incubated initially at $25{ }^{\circ} \mathrm{C}$ for $10 \mathrm{~min}$ and subsequently at $37{ }^{\circ} \mathrm{C}$ for $120 \mathrm{~min}$. Quantitative PCR (Taqman $^{\mathrm{TM}}$ ) assays chosen for the transcripts to be evaluated were from Assays-On-Demand ${ }^{\mathrm{TM}}$ (ABI), a prevalidated library of QPCR assays and were incorporated into 384-well MicroFluidic ${ }^{\mathrm{TM}}$ cards. All of the oligonucleotide primer and fluorogenic probe sets for Taqman $^{\mathrm{TM}}$ real time PCR in rats and mice were from ABI (Table 1). Two $\mu \mathrm{l}$ of the cDNA along with $50 \mu \mathrm{l}$ of $2 \mathrm{x}$ PCR master mixes were loaded into respective channels on the microfluidic card followed by a brief centrifugation. The card was then sealed and real-time PCR and relative quantification were carried out on the ABI PRISM 7900 Sequence Detection System. The cycle conditions were: $94.5{ }^{\circ} \mathrm{C}$ for $15 \mathrm{~min}$, followed by 40 cycles of $97^{\circ} \mathrm{C}$ for $30 \mathrm{~s}, 59.7^{\circ} \mathrm{C}$ for $1 \mathrm{~min}$. Data were analyzed using Sequence Detection Systems software (Applied Biosystems) and the Relative Quantification (RQ) method, which represents the fold difference of mRNA level in rats treated with GIP relative to rats treated with control or the $\mathrm{GIPR}^{-/}$mice relative to $\mathrm{GIPR}^{+/ ?}$ mice. Preliminary experiments were carried out to determine the most appropriate endogenous control gene to use to correct for differences in the amounts of total RNA added to each reaction. For the rat experiment, mRNA expressions were normalized with $18 \mathrm{~S}$ as an endogenous control to correct the differences in the amount of total RNA added to each reaction. $\beta$-ACT was used as endogenous control in the mouse experiment. The $\Delta \mathrm{C}_{\mathrm{T}}$ values were calculated initially using $\mathrm{C}_{\mathrm{T}}$ for a specific gene mRNA minus $\mathrm{C}_{\mathrm{T}}$ for $18 \mathrm{~S}$ mRNA (in rats) and $\beta$-ACT (in the mice) in the sample. The mean mRNA expressions from the rats treated with GIP were compared with those from the $a \mathrm{CSF}$ treated rats and mRNA expressions from the GIPR ${ }^{-/-}$mice were compared to those from the $\mathrm{GIPR}^{+/ \text {? }}$ mice using the formula: Relative Quantification (RQ) $=2^{-\Delta \Delta C T}\left(\Delta \Delta C_{T}\right.$ is the average control group $\Delta \mathrm{C}_{\mathrm{T}}$ values minus the average experimental group $\Delta \mathrm{C}_{\mathrm{T}}$ values, and $\Delta \Delta \mathrm{C}_{\mathrm{T}}$ of 1 equates to a two-fold difference in starting amount of $c$ DNA). The relative quantification values from each gene were used to compare the hypothalamic gene expression between two groups.

\section{Statistical analysis}

Food intake and body weight gain data were analyzed using the general linear model ANOVA (Statistica v. 7.1; StatSoft, Inc., Tulsa, OK). Fishers LSD test was used to determine significance among means, with $p<0.05$ considered significant. Data are expressed as means \pm S.E.M.

Gene expression data are shown as means \pm S.E.M. of relative quantification (RQ) values from the Sequence Detection System (SDS, ABI-Perkin Elmer, Foster City, CA) files for all the genes. Statistical significance was assessed by general linear model ANOVA for multiple comparisons between the means for the different treatment/genotype groups. The BenjaminiHochberg procedure was used to control for false discovery rate. A $p<0.05$ was considered to be significant. Multivariate analysis between genes was performed with Pearson correlation.

\section{Results}

Effect of icv administration of GIP on food intake and body weight of rats

GIP administered icv for 4 days in rats had no effect on food intake (data not shown). However, $10 \mu \mathrm{g}$ /day GIP caused a significant loss of body weight compared to control and the other GIP treatments (Fig. 1). This dose was then selected for determination of effects on hypothalamic gene expression.

Effect of icv administration of GIP on hypothalamic gene expression in rats

Increased hypothalamic mRNA expression levels were found for AVP $(46.9 \pm 4.5 \%)$, CART $(25.9 \pm 2.7 \%), \quad$ CREB1 $\quad(38.5 \pm 4.5 \%), \quad$ GABRD $(67.1 \pm 11 \%)$, JAK2 (22.1 $\pm 3.6 \%)$, MAPK1 (33.8 $\pm 7.8 \%)$, NPY $\quad(25.3 \pm 5.3 \%), \quad$ OXT $\quad(49.1 \pm 5.1 \%), \quad$ STAT3 $(21.6 \pm 3.8 \%)$, and $\mathrm{TH}(33.9 \pm 8.5 \%)$ after 4 days of icv injections of $10 \mu \mathrm{g} /$ day GIP in rats (Table 2). 
Table 1. Probes used for real time PCR.

\begin{tabular}{|c|c|c|c|c|}
\hline $\begin{array}{l}\text { Gene } \\
\text { symbol }\end{array}$ & Gene name & Rat ABI assay ID & $\begin{array}{l}\text { Mice ABI assay } \\
\text { ID }\end{array}$ & Function \\
\hline $18 S$ & & $4342379-18 \mathrm{~S}$ & ------- & House-keeping gene \\
\hline$\beta-A C T$ & actin, beta & ------- & Mm00607939_s1 & House-keeping gene \\
\hline$A V P$ & $\begin{array}{l}\text { arginine } \\
\text { vasopressin }\end{array}$ & Rn00566449_m1 & Mm00437761_g1 & $\begin{array}{l}\text { Neuroendocrine and feeding regulation } \\
\text { (Bray 2000, Landgraf 2006) }\end{array}$ \\
\hline$C A R T$ & $\begin{array}{l}\text { cocaine and } \\
\text { amphetamine } \\
\text { regulated } \\
\text { transcript }\end{array}$ & Rn00567382_m1 & Mm00489086_m1 & $\begin{array}{l}\text { Energy balance, bone metabolism, } \\
\text { anxiety (Asakawa et al. 2001, Kong et } \\
\text { al. 2003, Tian et al. 2004, Wortley et al. } \\
\text { 2004, Elefteriou et al. 2005) }\end{array}$ \\
\hline CREB 1 & $\begin{array}{l}\text { cAMP responsive } \\
\text { element binding } \\
\text { protein } 1\end{array}$ & Rn00578829_g1 & Mm00501607_m1 & $\begin{array}{l}\text { Learning, memory, anxiety, feeding } \\
\text { related circuits (Carlezon et al. 2005, } \\
\text { Duman and Duman 2005, Georgescu et } \\
\text { al. 2005, Altarejos and Montminy 2011) }\end{array}$ \\
\hline$M A P K 1$ & $\begin{array}{l}\text { mitogen activated } \\
\text { protein kinase } 1\end{array}$ & Rn00587719_m1 & Mm00442479_m1 & $\begin{array}{l}\text { Sympathetic activation, leptin and } \\
\text { insulin feeding circuits, circadian rhythm } \\
\text { (Coogan and Piggins 2004, Hegyi et al. } \\
\text { 2004, Rahmouni et al. 2004, Ambati et } \\
\text { al. 2007) }\end{array}$ \\
\hline$O X T$ & oxcytocin & Rn00564446_g1 & Mm00726655_s1 & $\begin{array}{l}\text { social behaviors, anxiety, feeding } \\
\text { behavior (Bale } \text { et al. 2001, Sabatier et al. } \\
\text { 2007, Veenema and Neumann 2008) }\end{array}$ \\
\hline$S C T$ & secretin & Rn00575360_g1 & Mm00441235_g1 & $\begin{array}{l}\text { Feeding behavior, autism (Ambati et al. } \\
\text { 2007, 2009, Lee et al. 2010, Cheng et al. } \\
\text { 2011) }\end{array}$ \\
\hline$T H$ & $\begin{array}{l}\text { tyrosine } \\
\text { hydroxylase }\end{array}$ & Rn00562500_m1 & Mm00447546_m1 & $\begin{array}{l}\text { Feeding, reward (Ambati et al. 2007, } \\
\text { 2009, Lee } \text { et al. 2010) }\end{array}$ \\
\hline GABRD & $\begin{array}{l}\text { gamma- } \\
\text { aminobutyric acid } \\
\text { A receptor, delta }\end{array}$ & Rn00568740_m1 & Mm00433476_ml & $\begin{array}{l}\text { Inhibitory neurotransmitter, cognition, } \\
\text { speech, feeding behavior } \\
\text { (Windpassinger et al. 2002, Ambati et } \\
\text { al. 2009) }\end{array}$ \\
\hline$J A K 2$ & Janus kinase 2 & Rn00580452_ml & Mm00434561_ml & $\begin{array}{l}\text { leptin signaling (Sandberg et al. 2004, } \\
\text { Villanueva and Myers 2008) }\end{array}$ \\
\hline$N P Y$ & neuropeptide $Y$ & Rn00561681_ml & Mm00445771_ml & $\begin{array}{l}\text { Feeding behavior (Kalra et al. 1991, } \\
\text { Kalra and Kalra 2003) }\end{array}$ \\
\hline POMC & $\begin{array}{l}\text { pro- } \\
\text { opiomelanocortin }\end{array}$ & Rn00595020_ml & Mm00435874_ml & $\begin{array}{l}\text { Feeding behavior (Boston 2001, Li et al. } \\
\text { 2003) }\end{array}$ \\
\hline PTGES & $\begin{array}{l}\text { prostaglandin E } \\
\text { synthase }\end{array}$ & Mm00456961_ml & Mm00452105_ml & $\begin{array}{l}\text { Inflammation, feeding behavior } \\
\text { (Turnbull and Rivier 1996, Ohinata et al. } \\
\text { 2008, Ambati et al. 2009) }\end{array}$ \\
\hline SOCS3 & $\begin{array}{l}\text { suppressor of } \\
\text { cytokine } \\
\text { signaling } 3 \\
\end{array}$ & Rn00585674_sl & Mm00545913_sl & $\begin{array}{l}\text { Leptin signaling, neuroimmuneendocrine } \\
\text { modulator (Auernhammer et al. 2000, } \\
\text { Morris and Rui 2009) }\end{array}$ \\
\hline STAT3 & $\begin{array}{l}\text { signal transducer } \\
\text { and activator of } \\
\text { transcription } 3\end{array}$ & Rn00562562_ml & Mm00456961_ml & $\begin{array}{l}\text { Signal transduction in feeding related } \\
\text { circuits (Carvalheira et al. 2001, Zhao et } \\
\text { al. 2002, Hommel et al. 2006, Gao et al. } \\
\text { 2007) }\end{array}$ \\
\hline
\end{tabular}

*POMC1, mouse; POMC2, rat. 


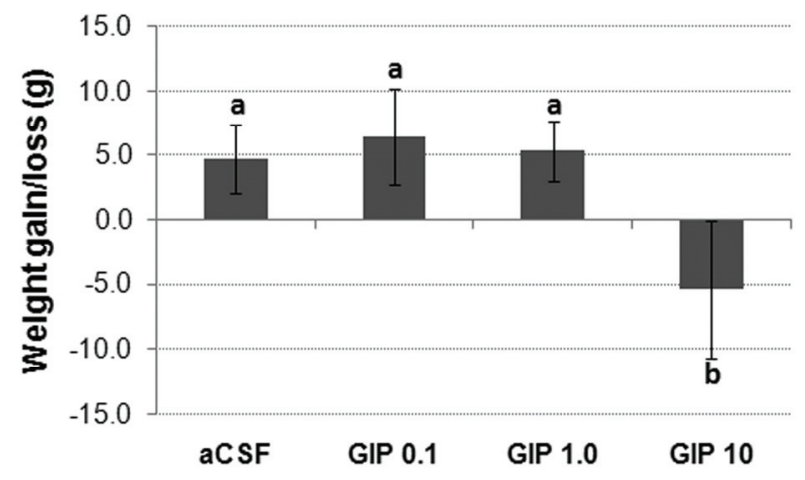

Fig. 1. Weight gain/loss in rats treated daily for 4 days with control (aCSF) or $10 \mu \mathrm{g} / \mathrm{d}$ GIP administered into the lateral cerebral ventricle. Data are means \pm S.E.M. Means not denoted with a common superscript are different, ${ }^{\mathrm{ab}} p<0.05$.

Correlation between CREB1 and MAPK1 mRNA expression levels in GIP-treated rats

The mRNA levels of both CREB1 and MAPK1 showed a proportional increase with a positive correlation (Correlation coefficient, $\mathrm{r}=0.87, \mathrm{p}<0.001$ ) in the hypothalamus of GIP-treated rats.

Hypothalamic gene expression in $\mathrm{GIPR}^{-/-}$and $\mathrm{GIPR}^{+/ ?}$ mice

The hypothalamic mRNA levels of some biomarkers were lower in hypothalami of $\mathrm{GIPR}^{-/}$mice when compared with those of wild-type controls. Relative to $\mathrm{GIPR}^{+/ \text {? }}$ mice, expression levels of hypothalamic mRNAs of AVP (27.1 $\pm 7.5 \%)$, CART (28.3 $\pm 3.7 \%)$, OXT $(25.2 \pm 5.8 \%)$, PTGES $(23.9 \pm 4.5 \%)$, and STAT3 $(8.8 \pm 2.3 \%)$ in $\mathrm{GIPR}^{-/}$mice were down-regulated (Table 2).

Hypothalamic mRNA expression of MAPK1 $(38.2 \pm 4.0 \%, \mathrm{p}<0.01)$ and NPY $(31.6+8.5 \%, \mathrm{p}<0.01)$ was increased in $\mathrm{GIPR}^{-/-}$mice relative to $\mathrm{GIPR}^{+/ ?}$ mice.

\section{Discussion}

GIP is considered to be one of the principle incretin factors of the enteroinsular axis system which has been implicated to play a critical role in the pathogenesis of diabetes and obesity (Wideman and Kieffer 2004, Yip and Wolfe 2000). The current study was designed to investigate the alterations in expression of hypothalamic genes involved in feeding behavior and energy balance regulation in rats treated icv with GIP and in GIPR deficient mice.

AVP is suggested to trigger a variety of effects relating to regulation of water, glucose and electrolytes and neuroendocrine functions and may also play a role in energy balance regulation (Bray 2000, Landgraf 2006). The structurally-related neuropeptide oxytocin (OXT) has also been implicated in feeding, complex social behaviors and anxiety-associated behaviors (Bale et al. 2001, Sabatier et al. 2007). Higher levels of AVP and OXT mRNA expression were found following icv GIP treatment in rats. Furthermore, both AVP and OXT expressions were lower in $\mathrm{GIPR}^{-/}$mice, thus suggesting that these hypothalamic neuropeptides may mediate GIP-induced behavioral changes related to energy balance regulation.

Cocaine- and amphetamine-regulated transcript (CART) is highly expressed in the hypothalamus, particularly in the paraventricular (PVN) and arcuate (ARC) nuclei (Couceyro et al. 1997), which are critical in the regulation of energy homeostasis. CART was originally reported to be an anorectic neuropeptide, based on icv administration of CART(55-102) (Kristensen et al. 1998, Stanley et al. 2001) and on overexpression of CART after administration of recombinant adeno-associated virus (rAAV)-CART into the third ventricle in diet-induced obese rats (Qing and Chen, 2007). However, icv administration of CART is also associated with motor disturbances which may interfere with feeding (Aja et al. 2001). In contrast, direct administration of CART (55-102) into discrete hypothalamic nuclei (Abbott et al. 2001) and over-expression of CART in the ARC (Kong et al. 2003) and PVN (Smith et al. 2008) have been shown to increase food intake and weight gain.

In our study hypothalamic CART expression was increased in rats treated icv with GIP and decreased in mice deficient in GIPR. Although GIP did not affect food intake in the rats, it did cause weight loss, and a previous study has shown that overexpression of GIP in mice resulted in enhanced locomotor behavior and no increase in anxiety behavior (Ding et al. 2006). Thus, the changes in whole hypothalamic CART expression may be related to the effect of GIP on energy balance regulation, but probably not through changes in anxiety or locomotor behavior.

STAT proteins are a family of cytoplasmic transcription factors activated by tyrosine phosphorylation and dimerization in response to cytokines, growth factors and other extracellular ligands (Dandoy-Dron et al. 1995, Sano et al. 1999). In particular, STAT3 has been shown to play an important role in the regulation of energy balance. STAT3 is a known downstream component of both leptin and ciliary neurotrophic factor (CNTF) action (Hubschle et al. 2001, Lambert et al. 2001). Mice with STAT3 deletion 
Table 2. Hypothalamic mRNA expression (mean \pm S.E.M.) of hypothalamic genes in $\mathrm{GIPR}^{+/ \text {? }}$ and $\mathrm{GIPR}^{-/}$mice* and in rats** after 4 days ICV injection of 0 or $10 \mu \mathrm{g} / \mathrm{d}$ GIP.

\begin{tabular}{|c|c|c|c|c|}
\hline Gene & GIPR $^{+/ ?}$ mice & GIPR $^{-/-}$mice & $\begin{array}{c}\text { Rats } \\
(0 \mu \mathrm{g} / \mathrm{d} \text { GIP ICV })\end{array}$ & $\begin{array}{c}\text { Rats } \\
(10 \mu \mathrm{g} / \mathrm{d} \text { GIP ICV })\end{array}$ \\
\hline$A V P$ & $0.85 \pm 0.09^{\mathrm{a}}$ & $0.62 \pm 0.08^{b}$ & $0.78 \pm 0.06^{\mathrm{x}}$ & $1.14 \pm 0.03^{y}$ \\
\hline$C A R T$ & $0.7 \pm 0.05^{\mathrm{a}}$ & $0.50 \pm 0.03^{b}$ & $0.97 \pm 0.07^{\mathrm{a}}$ & $1.22 \pm 0.02^{\mathrm{b}}$ \\
\hline CREBI & $1.08 \pm 0.02$ & $1.04 \pm 0.02$ & $0.81 \pm 0.04^{x}$ & $1.12 \pm 0.03^{y}$ \\
\hline GABRD & $1.44 \pm 0.1$ & $1.52 \pm 0.05$ & $0.89 \pm 0.03^{\mathrm{x}}$ & $1.49 \pm 0.1^{\mathrm{y}}$ \\
\hline$J A K 2$ & $1.16 \pm 0.04$ & $1.2 \pm 0.03$ & $0.84 \pm 0.06^{\mathrm{a}}$ & $1.03 \pm 0.03^{b}$ \\
\hline MAPK1 & $1.31 \pm 0.06^{\mathrm{x}}$ & $1.82 \pm 0.07^{y}$ & $0.85 \pm 0.06^{\mathrm{a}}$ & $1.14 \pm 0.06^{\mathrm{b}}$ \\
\hline$N P Y$ & $1.29 \pm 0.06^{\mathrm{a}}$ & $1.7 \pm 0.11^{\mathrm{b}}$ & $0.75 \pm 0.06^{\mathrm{a}}$ & $0.94 \pm 0.05^{b}$ \\
\hline$O X T$ & $0.8 \pm 0.06^{\mathrm{a}}$ & $0.6 \pm 0.06^{\mathrm{b}}$ & $0.85 \pm 0.09^{x}$ & $1.27 \pm 0.04^{\mathrm{y}}$ \\
\hline POMC & $0.85 \pm 0.09$ & $0.66 \pm 0.14$ & $0.75 \pm 0.07$ & $0.85 \pm 0.04$ \\
\hline PTGES & $1.17 \pm 0.07^{\mathrm{a}}$ & $0.89 \pm 0.04^{b}$ & $0.93 \pm 0.06$ & $1.08 \pm 0.06$ \\
\hline$S C T$ & $1.1 \pm 0.15$ & $0.83 \pm 0.10$ & $0.85 \pm 0.08$ & $1.14 \pm 0.01$ \\
\hline$S O C S 3$ & $1.32 \pm 0.15$ & $0.84 \pm 0.06$ & $0.90 \pm 0.07$ & $0.95 \pm 0.04$ \\
\hline STAT3 & $1.15 \pm 0.03^{\mathrm{a}}$ & $1.05 \pm 0.03^{b}$ & $0.79 \pm 0.06^{\mathrm{a}}$ & $0.96 \pm 0.03^{b}$ \\
\hline$T H$ & $0.85 \pm 0.07$ & $0.7 \pm 0.04$ & $0.76 \pm 0.09^{\mathrm{a}}$ & $1.01 \pm 0.06^{\mathrm{b}}$ \\
\hline
\end{tabular}

*Data are normalized to $\beta$-ACT values; **Data are normalized to the $18 \mathrm{~S}$ values; means with different superscripts are different ${ }^{\text {ab }} p<0.05 ;{ }^{\mathrm{xy}} p<0.01$.

in leptin receptor positive neurons of the hypothalamus become hyperphagic after weaning, have increased body weight and body fat, and exhibit impaired glucose tolerance (Cui et al. 2004). While phosphorylation levels of STAT3 are believed to be more critical than variations of mRNA level, our previous study showed that mRNA levels of STAT3 in the arcuate nucleus/median eminence of the hypothalamus were significantly up-regulated in rats with ICV treatment of leptin or CNTF (Ambati et al. 2007). The results from the present study show increased expression of STAT3 in the hypothalamus of rats treated icv with GIP and decreased expression of hypothalamic STAT3 in mice deficient in GIPR. Thus, STAT3 may also be a downstream transcription factor involved in the central effect of GIP on energy balance regulation.

GABRD is a receptor for gamma-aminobutyric acid, an inhibitory neuropeptide involved in a number of hypothalamic and higher brain functions, including neuronal network development, cognition and speech (Windpassinger et al. 2002). CREB1 protein is a transcription factor and usually considered a marker of neuron activation (Zachariou et al. 2001). In rats treated icv with GIP, GABRD and CREB1 mRNA expression was increased, suggesting elevated neuronal activity as a response to GIP treatment. Interestingly, proportionate increase in mRNA expression levels of CREB1 and
MAPK1 in the hypothalamus of GIP-treated rats indicated a possible MAPK-1 signaling-dependent neuron activation by CREB1 (Pandey 2003, Euskirchen et al. 2004). CREB1 plays a regulatory role in the nervous system and is widely believed to promote neuronal survival, precursor proliferation and other neuronal-related functions (Rodriguez and Ferrer 2007). Phosphorylation of CREB1 through MAPK signaling is a critical event in the network of neuronal activation, neuronal proliferation, differentiation and synaptic function. Activation of this network also stimulates neurite outgrowth in the central nervous system and also in neuronal cell-lines (Ma'ayan et al. 2009). Furthermore, there is evidence that phosphorylation of CREB regulates NPY expression in the brain (Pandey 2003).

In conclusion, our data suggest that GIP and its receptor may be involved in energy balance regulation by the hypothalamus as evident by the changes in expression levels of genes such as AVP, CART, OXT, and STAT3.

\section{Conflict of Interest}

There is no conflict of interest.

\section{Acknowledgements}

This work was supported in part by Georgia Research Alliance Eminent Scholar endowment held by CAB. 


\section{References}

ABBOTT CR, ROSSI M, WREN AM, MURPHY KG, KENNEDY AR, STANLEY SA, ZOLLNER AN, MORGAN DG, MORGAN I, GHATEI MA, SMALL CJ, BLOOM SR: Evidence of an orexigenic role for cocaine- and amphetamine-regulated transcript after administration into discrete hypothalamic nuclei. Endocrinology 142: 3457-3463, 2001.

AJA S, SCHWARTZ GJ, KUHAR MJ, MORAN TH: Intracerebroventricular CART peptide reduces rat ingestive behavior and alters licking microstructure. Am J Physiol Regul Integr Comp Physiol 280: R1613-R1619, 2001.

ALTAREJOS JY, MONTMINY M: CREB and the CRTC co-activators: sensors for hormonal and metabolic signals. Nat Rev Mol Cell Biol 12: 141-151, 2011.

AMBATI S, DUAN J, CHOI YH, HARTZELL DL, DELLA-FERA MA, BAILE CA: ICV vs. VMH injection of leptin: Comparative effects on hypothalamic gene expression. Behav Brain Res 196: 279-285, 2009.

AMBATI S, DUAN J, DUFF E, CHOI YH, HARTZELL DL, DELLA-FERA MA, BAILE CA: Gene expression in arcuate nucleus of rats treated with leptin or ciliary neurotrophic factor. Biofactors 31: 133-144, 2007.

ASAKAWA A, INUI A, YUZURIHA H, NAGATA T, KAGA T, UENO N, FUJINO MA, KASUGA M: Cocaineamphetamine-regulated transcript influences energy metabolism, anxiety and gastric emptying in mice. Horm Metab Res 33: 554-558, 2001.

AUERNHAMMER CJ, BOUSQUET C, CHESNOKOVA V, MELMED S: SOCS proteins: modulators of neuroimmunoendocrine functions. Impact on corticotroph LIF signaling. Ann N Y Acad Sci 917: 658-664, 2000.

BALE TL, DAVIS AM, AUGER AP, DORSA DM, MCCARTHY MM: CNS region-specific oxytocin receptor expression: importance in regulation of anxiety and sex behavior. $J$ Neurosci 21: 2546-2552, 2001.

BOSTON BA: Pro-opiomelanocortin and weight regulation: from mice to men. J Pediatr Endocrinol Metab 14 (Suppl 6): 1409-1416, 2001.

BRAY GA: Afferent signals regulating food intake. Proc Nutr Soc 59: 373-384, 2000.

BUCHAN AM, POLAK JM, CAPELLA C, SOLCIA E, PEARSE AG: Electronimmunocytochemical evidence for the K cell localization of gastric inhibitory polypeptide (GIP) in man. Histochemistry 56: 37-44, 1978.

CARLEZON WA JR, DUMAN RS, NESTLER EJ: The many faces of CREB. Trends Neurosci 28: 436-445, 2005.

CARVALHEIRA JB, SILOTO RM, IGNACCHITTI I, BRENELLI SL, CARVALHO CR, LEITE A, VELLOSO LA, GONTIJO JA, SAAD MJ: Insulin modulates leptin-induced STAT3 activation in rat hypothalamus. FEBS Lett 500: 119-124, 2001.

CHENG CY, CHU JY, CHOW BK: Central and peripheral administration of secretin inhibits food intake in mice through the activation of the melanocortin system. Neuropsychopharmacology 36: 459-471, 2011.

CHOI YH, LI C, PAGE K, WESTBY A, DELLA-FERA MA, LIN J, HARTZELL DL, BAILE CA: Melanocortin receptors mediate leptin effects on feeding and body weight but not adipose apoptosis. Physiol Behav 79: 795$801,2003$.

COOGAN AN, PIGGINS HD: MAP kinases in the mammalian circadian system--key regulators of clock function. J Neurochem 90: 769-775, 2004.

COUCEYRO PR, KOYLU EO, KUHAR MJ: Further studies on the anatomical distribution of CART by in situ hybridization. J Chem Neuroanat 12: 229-241, 1997.

CUI Y, HUANG L, ELEFTERIOU F, YANG G, SHELTON JM, GILES JE, OZ OK, POURBAHRAMI T, LU CY, RICHARDSON JA, KARSENTY G, LI C: Essential role of STAT3 in body weight and glucose homeostasis. Mol Cell Biol 24: 258-269, 2004.

DANDOY-DRON F, ITIER JM, MONTHIOUX E, BUCCHINI D, JAMI J: Tissue-specific expression of the rat insulin 1 gene in vivo requires both the enhancer and promoter regions. Differentiation 58: 291-295, 1995.

DING KH, SHI XM, ZHONG Q, KANG B, XIE D, BOLLAG WB, BOLLAG RJ, HILL W, WASHINGTON W, MI QS, INSOGNA K, CHUTKAN N, HAMRICK M, ISALES CM: Impact of glucose-dependent insulinotropic peptide on age-induced bone loss. J Bone Miner Res 23: 536-543, 2008. 
DING KH, ZHONG Q, XIE D, CHEN HX, DELLA-FERA MA, BOLLAG RJ, BOLLAG WB, GUJRAL R, KANG B, SRIDHAR S, BAILE C, CURL W, ISALES CM: Effects of glucose-dependent insulinotropic peptide on behavior. Peptides 27: 2750-2755, 2006.

DUMAN CH, DUMAN RS: Neurobiology and treatment of anxiety: signal transduction and neural plasticity. Handb Exp Pharmacol 169: 305-334, 2005.

ELEFTERIOU F, AHN JD, TAKEDA S, STARBUCK M, YANG X, LIU X, KONDO H, RICHARDS WG, BANNON TW, NODA M, CLEMENT K, VAISSE C, KARSENTY G: Leptin regulation of bone resorption by the sympathetic nervous system and CART. Nature 434: 514-520, 2005.

EUSKIRCHEN G, ROYCE TE, BERTONE P, MARTONE R, RINN JL, NELSON FK, SAYWARD F, LUSCOMBE NM, MILLER P, GERSTEIN M, WEISSMAN S, SNYDER M: CREB binds to multiple loci on human chromosome 22. Mol Cell Biol 24: 3804-3814, 2004.

GAO Q, MEZEI G, NIE Y, RAO Y, CHOI CS, BECHMANN I, LERANTH C, TORAN-ALLERAND D, PRIEST CA, ROBERTS JL, GAO XB, MOBBS C, SHULMAN GI, DIANO S, HORVATH TL: Anorectic estrogen mimics leptin's effect on the rewiring of melanocortin cells and Stat3 signaling in obese animals. Nat Med 13: 89-94, 2007.

GEORGESCU D, SEARS RM, HOMMEL JD, BARROT M, BOLANOS CA, MARSH DJ, BEDNAREK MA, BIBB JA, MARATOS-FLIER E, NESTLER EJ, DILEONE RJ: The hypothalamic neuropeptide melaninconcentrating hormone acts in the nucleus accumbens to modulate feeding behavior and forced-swim performance. J Neurosci 25: 2933-2940, 2005.

HAUNER H, GLATTING G, KAMINSKA D, PFEIFFER EF: Effects of gastric inhibitory polypeptide on glucose and lipid metabolism of isolated rat adipocytes. Ann Nutr Metab 32: 282-288, 1988.

HEGYI K, FULOP K, KOVACS K, TOTH S, FALUS A: Leptin-induced signal transduction pathways. Cell Biol Int 28: 159-169, 2004.

HOLST JJ: On the physiology of GIP and GLP-1. Horm Metab Res 36: 747-754, 2004.

HOMMEL JD, TRINKO R, SEARS RM, GEORGESCU D, LIU ZW, GAO XB, THURMON JJ, MARINELLI M, DILEONE RJ: Leptin receptor signaling in midbrain dopamine neurons regulates feeding. Neuron 51: 801$810,2006$.

HUBSCHLE T, THOM E, WATSON A, ROTH J, KLAUS S, MEYERHOF W: Leptin-induced nuclear translocation of STAT3 immunoreactivity in hypothalamic nuclei involved in body weight regulation. $J$ Neurosci 21: 24132424, 2001.

KALRA SP, DUBE MG, SAHU A, PHELPS CP, KALRA PS: Neuropeptide Y secretion increases in the paraventricular nucleus in association with increased appetite for food. Proc Natl Acad Sci USA 88: 1093110935, 1991.

KALRA SP, KALRA PS: Neuropeptide Y: a physiological orexigen modulated by the feedback action of ghrelin and leptin. Endocrine 22: 49-56, 2003.

KAPLAN AM, VIGNA SR: Gastric inhibitory polypeptide (GIP) binding sites in rat brain. Peptides 15: 297-302, 1994.

KIEFFER TJ: GIP or not GIP? That is the question. Trends in pharmacological sciences 24: 110-112, 2003.

KONG WM, STANLEY S, GARDINER J, ABBOTT C, MURPHY K, SETH A, CONNOLEY I, GHATEI M, STEPHENS D, BLOOM S: A role for arcuate cocaine and amphetamine-regulated transcript in hyperphagia, thermogenesis, and cold adaptation. FASEB J 17: 1688-1690, 2003.

KRISTENSEN P, JUDGE ME, THIM L, RIBEL U, CHRISTJANSEN KN, WULFF BS, CLAUSEN JT, JENSEN PB, MADSEN OD, VRANG N, LARSEN PJ, HASTRUP S: Hypothalamic CART is a new anorectic peptide regulated by leptin. Nature 393: 72-76, 1998.

LAMBERT PD, ANDERSON KD, SLEEMAN MW, WONG V, TAN J, HIJARUNGURU A, CORCORAN TL, MURRAY JD, THABET KE, YANCOPOULOS GD, WIEGAND SJ: Ciliary neurotrophic factor activates leptin-like pathways and reduces body fat, without cachexia or rebound weight gain, even in leptin-resistant obesity. Proc Natl Acad Sci USA 98: 4652-4657, 2001.

LANDGRAF R: The involvement of the vasopressin system in stress-related disorders. CNS Neurol Disord Drug Targets 5: 167-179, 2006. 
LEE AK, MOJTAHED-JABERI M, KYRIAKOU T, ALDECOA-OTALORA ASTARLOA E, ARNO M, MARSHALL NJ, BRAIN SD, O'DELL SD: Effect of high-fat feeding on expression of genes controlling availability of dopamine in mouse hypothalamus. Nutrition 26: 411-422, 2010.

LI G, MOBBS CV, SCARPACE PJ: Central pro-opiomelanocortin gene delivery results in hypophagia, reduced visceral adiposity, and improved insulin sensitivity in genetically obese Zucker rats. Diabetes 52: 1951-1957, 2003.

MA'AYAN A, JENKINS SL, BARASH A, IYENGAR R: Neuro2A differentiation by Galphai/o pathway. Sci Signal 2: cm1, 2009.

MIYAWAKI K, YAMADA Y, BAN N, IHARA Y, TSUKIYAMA K, ZHOU H, FUJIMOTO S, OKU A, TSUDA K, TOYOKUNI S, HIAI H, MIZUNOYA W, FUSHIKI T, HOLST JJ, MAKINO M, TASHITA A, KOBARA Y, TSUBAMOTO Y, JINNOUCHI T, JOMORI T, SEINO Y: Inhibition of gastric inhibitory polypeptide signaling prevents obesity. Nat Med 8: 738-742, 2002.

MIYAWAKI K, YAMADA Y, YANO H, NIWA H, BAN N, IHARA Y, KUBOTA A, FUJIMOTO S, KAJIKAWA M, KUROE A, TSUDA K, HASHIMOTO H, YAMASHITA T, JOMORI T, TASHIRO F, MIYAZAKI J, SEINO Y: Glucose intolerance caused by a defect in the entero-insular axis: a study in gastric inhibitory polypeptide receptor knockout mice. Proc Natl Acad Sci USA 96: 14843-14847, 1999.

MOENS K, HEIMBERG H, FLAMEZ D, HUYPENS P, QUARTIER E, LING Z, PIPELEERS D, GREMLICH S, THORENS B, SCHUIT F: Expression and functional activity of glucagon, glucagon-like peptide I, and glucose-dependent insulinotropic peptide receptors in rat pancreatic islet cells. Diabetes 45: 257-261, 1996.

MORRIS DL, RUI L: Recent advances in understanding leptin signaling and leptin resistance. Am J Physiol Endocrinol Metab 297: E1247-E1259, 2009.

NYBERG J, ANDERSON MF, MEISTER B, ALBORN AM, STROM AK, BREDERLAU A, ILLERSKOG AC, NILSSON O, KIEFFER TJ, HIETALA MA, RICKSTEN A, ERIKSSON PS: Glucose-dependent insulinotropic polypeptide is expressed in adult hippocampus and induces progenitor cell proliferation. J Neurosci 25: 1816-1825, 2005.

OHINATA K, TAKAGI K, BIYAJIMA K, FUJIWARA Y, FUKUMOTO S, EGUCHI N, URADE Y, ASAKAWA A, FUJIMIYA M, INUI A, YOSHIKAWA M: Central prostaglandin $\mathrm{D}(2)$ stimulates food intake via the neuropeptide Y system in mice. FEBS Lett 582: 679-684, 2008.

PANDEY SC: Anxiety and alcohol abuse disorders: a common role for CREB and its target, the neuropeptide Y gene. Trends Pharmacol Sci 24: 456-460, 2003.

QING K, CHEN Y: Central CART gene delivery by recombinant AAV vector attenuates body weight gain in dietinduced-obese rats. Regul Pept 140: 21-26, 2007.

RAHMOUNI K, MORGAN DA, MORGAN GM, LIU X, SIGMUND CD, MARK AL, HAYNES WG: Hypothalamic PI3K and MAPK differentially mediate regional sympathetic activation to insulin. J Clin Invest 114: 652-658, 2004.

RODRIGUEZ A, FERRER I: Expression of transcription factors CREB and c-Fos in the brains of terminal CreutzfeldtJakob disease cases. Neurosci Lett 421: 10-15, 2007.

SABATIER N, ROWE I, LENG G: Central release of oxytocin and the ventromedial hypothalamus. Biochem Soc Trans 35: 1247-1251, 2007.

SANDBERG EM, MA X, VONDERLINDEN D, GODENY MD, SAYESKI PP: Jak2 tyrosine kinase mediates angiotensin II-dependent inactivation of ERK2 via induction of mitogen-activated protein kinase phosphatase 1. J Biol Chem 279: 1956-1967, 2004.

SANO S, ITAMI S, TAKEDA K, TARUTANI M, YAMAGUCHI Y, MIURA H, YOSHIKAWA K, AKIRA S, TAKEDA J: Keratinocyte-specific ablation of Stat3 exhibits impaired skin remodeling, but does not affect skin morphogenesis. EMBO J 18: 4657-4668, 1999.

SHERWOOD NM, KRUECKL SL, MCRORY JE: The origin and function of the pituitary adenylate cyclase-activating polypeptide (PACAP)/glucagon superfamily. Endocr Rev 21: 619-670, 2000.

SMITH KL, GARDINER JV, WARD HL, KONG WM, MURPHY KG, MARTIN NM, GHATEI MA, BLOOM SR: Overexpression of CART in the PVN increases food intake and weight gain in rats. Obesity (Silver Spring) 16: 2239-2244, 2008. 
SONDHI S, CASTELLANO JM, CHONG VZ, ROGOZA RM, SKOBLENICK KJ, DYCK BA, GABRIELE J, THOMAS N, KI K, PRISTUPA ZB, SINGH AN, MACCRIMMON D, VORUGANTI P, FOSTER J, MISHRA RK: cDNA array reveals increased expression of glucose-dependent insulinotropic polypeptide following chronic clozapine treatment: role in atypical antipsychotic drug-induced adverse metabolic effects. Pharmacogenomics J 6: 131-140, 2006.

STANLEY SA, SMALL CJ, MURPHY KG, RAYES E, ABBOTT CR, SEAL LJ, MORGAN DG, SUNTER D, DAKIN CL, KIM MS, HUNTER R, KUHAR M, GHATEI MA, BLOOM SR: Actions of cocaine- and amphetamine-regulated transcript (CART) peptide on regulation of appetite and hypothalamo-pituitary axes in vitro and in vivo in male rats. Brain Res 893: 186-194, 2001.

TIAN DR, LI XD, SHI YS, WAN Y, WANG XM, CHANG JK, YANG J, HAN JS: Changes of hypothalamic alphaMSH and CART peptide expression in diet-induced obese rats. Peptides 25: 2147-2153, 2004.

TURNBULL AV, RIVIER C: Corticotropin-releasing factor, vasopressin, and prostaglandins mediate, and nitric oxide restrains, the hypothalamic-pituitary-adrenal response to acute local inflammation in the rat. Endocrinology 137: 455-463, 1996.

USDIN TB, MEZEY E, BUTTON DC, BROWNSTEIN MJ, BONNER TI: Gastric inhibitory polypeptide receptor, a member of the secretin-vasoactive intestinal peptide receptor family, is widely distributed in peripheral organs and the brain. Endocrinology 133: 2861-2870, 1993.

VEENEMA AH, NEUMANN ID: Central vasopressin and oxytocin release: regulation of complex social behaviours. Prog Brain Res 170: 261-276, 2008.

VILLANUEVA EC, MYERS MG JR: Leptin receptor signaling and the regulation of mammalian physiology. Int $J$ Obes (Lond) 32 (Supp1 7): S8-S12, 2008.

WASADA T, HARRIS V, KAWAI K, HOWARD B, UGER RH: Effects of gastric inhibitory polypeptide on plasma levels of chylomicron triglycerides in dogs. J Clin Invest 68: 1106-1107, 1981.

WIDEMAN RD, KIEFFER TJ: Glucose-dependent insulinotropic polypeptide as a regulator of beta cell function and fate. Horm Metab Res 36: 782-786, 2004.

WINDPASSINGER C, KROISEL PM, WAGNER K, PETEK E: The human gamma-aminobutyric acid A receptor delta (GABRD) gene: molecular characterisation and tissue-specific expression. Gene 292: 25-31, 2002.

WORTLEY KE, CHANG GQ, DAVYDOVA Z, FRIED SK, LEIBOWITZ SF: Cocaine- and amphetamine-regulated transcript in the arcuate nucleus stimulates lipid metabolism to control body fat accrual on a high-fat diet. Regul Pept 117: 89-99, 2004.

YIP RG, WOLFE MM: GIP biology and fat metabolism. Life Sci 66: 91-103, 2000.

ZACHARIOU V, GEORGESCU D, KANSAL L, MERRIAM P, PICCIOTTO MR: Galanin receptor 1 gene expression is regulated by cyclic AMP through a CREB-dependent mechanism. J Neurochem 76: 191-200, 2001.

ZHAO AZ, HUAN JN, GUPTA S, PAL R, SAHU A: A phosphatidylinositol 3-kinase phosphodiesterase 3B-cyclic AMP pathway in hypothalamic action of leptin on feeding. Nat Neurosci 5: 727-728, 2002. 